\title{
PENANGANGAN BANTUAN HIDUP DASAR (BHD) DAN KESEHATAN DAN KESELAMATAN KERJA (K3) LINGKUNGAN RUMAH TANGGA
}

\author{
Andhi Fahrurroji ${ }^{1 *}$, Arif Wicaksono², Suhaimi Fauzan ${ }^{3}$, Agus Fitriangga ${ }^{2}$, Faisal Kholid \\ Fahdi $^{3}$, Siti Nani Nurbaeti ${ }^{1}$
}

\author{
${ }^{1}$ Jurusan Farmasi, Fakultas Kedokteran, Universitas Tanjungpura, Pontianak, Indonesia \\ ${ }^{2}$ Jurusan Kedokteran, Fakultas Kedokteran, Universitas Tanjungpura, Pontianak, Indonesia \\ ${ }^{3}$ Jurusan Keperawatan, Fakultas Kedokteran, Universitas Tanjungpura, Pontianak, Indonesia \\ *Penulis korespondensi: roji_apt@pharm.untan.ac.id
}

\begin{abstract}
Abstrak
Kecelakaan bisa terjadi kapan pun, di mana pun dan dapat pula menimpa siapa saja. Umumnya, kecelakaan pun menjadi penyebab utama trauma yang kemudian menyebabkan kematian. cedera kecelakaan lalu lintas dan kematian yang terjadi sudah menjadi masalah sangat serius. Prevalensi cedera hasil Riskesdas 2013 meningkat dibandingkan Riskesdas 2007, penyebab akibat kecelakaan sepeda motor 40,6 persen, terbanyak pada laki-laki dan berusia 15-24 tahun. Proporsi cedera karena kecelakaan transportasi darat (sepeda motor dan kendaraan lain) meningkat dari 25,9 persen menjadi 47,7 persen. Dalam menghadapi kasus kecelakaan dengan kondisi kegawatdaruratan diperlukan suatu keterampilan usaha untuk mengembalikan dan mempertahankan fungsi vital organ pada korban kecelakaan atau biasa disebut bantuan hidup dasar. Adapun dalam kegiatan pengabdian kepada masyarakat (PKM) ini dilakukan dengan tahapan melakukan kegiatan sosialisasi dengan kepala dan pegawai puskesmas, petugas kesehatan, beserta kader tentang pelatihan penanganan bantuan hidup dasar (BHD) dan k3 lingkungan rumah tangga, Pengidentifikasian kader kesehatan sebagai calon peserta tersebut lingkungan rumah tangga kepada kader dan evaluasi dan monitoring hasil kegiatan. Berdasarkan hasil pelatihan, pengetahuan kader tentang penanganan BHD dan K3 lingkungan rumah tangga meningkat. dalam hal ini pengetahuan yang didapatkan peserta yaitu mengenai teknik dalam memberikan bantuan hidup dasar khususnya resusitasi jantung paru (RJP).
\end{abstract}

Kata Kunci : Kecelakaan; Bantuan Hidup Dasar; K3 Rumah Tangga; Resusitasi Jantung Paru.

\begin{abstract}
Accidents can happen anytime, anywhere and anyone. Generally, accidents also become the main cause of trauma which then causes death. Traffic accident injuries and deaths that occur have become very serious problems. The prevalence of injury results from Indonesia Basic Health Research (Riskesdas) 2013 increased compared to Riskesdas 2007. The proportion of injuries due to land transportation accidents (motorbikes and other vehicles) increased from 25.9 percent to 47.7 percent. In dealing with accident cases with emergency conditions, a skill is needed to restore and maintain the vital functions of organs in the accident commonly called basic life support (BLS). These activities are carried out with the stages of conducting socialization activities with the head and staff of the health center, health workers, and cadres on training in handling BLS and household safety, Identification of health cadres as prospective participants in BLS, and evaluation and monitoring of activity results. Based on the results of the training, knowledge of cadres about handling BLS and Health Safety in the household environment increased. In this case, the knowledge gained by participants namely about techniques in providing basic life support, especially cardiac pulmonary resuscitation (CPR).
\end{abstract}

Keywords: Accident; Basic Life Support; Household Health Safety; Cardiac Pulmonary Resuscitation.

\section{PENDAHULUAN}

Kecelakaan bisa terjadi kapan pun, di mana pun dan dapat pula menimpa siapa saja. Umumnya, kecelakaan pun menjadi penyebab utama trauma yang kemudian menyebabkan kematian. Terdapat 80 persen orang yang mengalami kecelakaan biasanya akan mengalami gangguan sistem musculoskeletal. Sementara 50 persennya bisa saja meninggal pada saat kecelakaan atau beberapa menit setelah kecelakaan. Badan Kesehatan Dunia atau World Health Organization (WHO) menyatakan, kecelakaan lalu lintas di jalan raya merupakan penyebab kedua terbesar di dunia yang mengakibatkan banyak korban meninggal dunia. Dalam setiap satu jamnya terdapat empat orang meninggal dunia akibat kecelakaan lalu lintas. Sebanyak $72 \%$ kasus kecelakaan lalu lintas tersebut 
terjadi di Indonesia. Kecelakaan yang melibatkan sepeda motor mencapai $73 \%$, disusul mobil (15\%), truk $(8 \%)$, bus $(2 \%)$, dan sepeda $2 \%$. (WHO, 2015)

Demikian pula di Indonesia, cedera kecelakaan lalu lintas dan kematian yang terjadi sudah menjadi masalah sangat serius. Prevalensi cedera hasil Riskesdas 2013 meningkat dibandingkan Riskesdas 2007, penyebab akibat kecelakaan sepeda motor 40,6 persen, terbanyak pada laki-laki dan berusia 15-24 tahun. Proporsi cedera karena kecelakaan transportasi darat (sepeda motor dan kendaraan lain) meningkat dari 25,9 persen menjadi 47,7 persen (Balitbangkes, 2013).

Sementara itu, kecelakaan tidak hanya dapat terjadi di jalan raya atau di tempat kerja. Banyak orang yang mungkin berpikir bahwa rumah adalah tempat teraman. Namun kenyataannya, banyak bahaya dan risiko yang mengintai dalam lingkungan rumah tangga. Bahaya dan risiko ini termasuk, antara lain, kasus kebakaran, keracunan makanan, zat-zat kimia, kecelakaan dan sebagainya yang mungkin saja termasuk kedalam kondisi kegawatdaruratan. Dalam menghadapi kasus kecelakaan dengan kondisi kegawatdaruratan diperlukan suatu keterampilan usaha untuk mengembalikan dan mempertahankan fungsi vital organ pada korban kecelakaan atau biasa disebut bantuan hidup dasar.

Keterampilan bantuan hidup dasar ini dapat diajarkan kepada siapa saja tidak hanya kepada tenaga kesehatan namun termasuk kepada masyarakat umum. Hal ini dikarenakan setiap orang idealnya memiliki kemampuan basic life support atau bantuan hidup dasar (BHD). Keterampilan BHD menjadi penting karena didalamnya diajarkan mengenai teknik dasar penyelamatan korban dari berbagai kecelakaan atau musibah sehari-hari yang biasa dijumpai (Fajarwati, 2012).

Tenaga kesehatan yang memiliki kemampuan dalam pemberian BHD hendaknya dapat mengajarkan masyarakat umum, namun realita yang ada di masyarakat pengetahuan maupun keterampilan yang dimiliki oleh kader maupun masyarakat awam mengenai BHD dan penanganannya belum memadai. Hal ini dapat dilihat dari hasil survey yang dilakukan oleh Aryani\&Amelia (2016) di Yogyakarta dimana sebagian besar kader tidak pernah mendapatkan pelatihan kegawatdaruratan masyarakat (56,3\%), memiliki persepsi tingkat kesiapan individu dalam menghadapi kasus kegawatdaruratan yang rendah $(55,3 \%)$, kader belum mampu melakukan BHD $(87,4 \%)$, manajemen tersedak $(86,8 \%)$, dan melakukan teknik balutan di bagian tubuh yang paling sering terkena luka $(88,3 \%)$.

Kota Pontianak memiliki angka kecelakaan lalu lintas terbilang tinggi. Berdasarkan data Satuan Lalu Lintas Polresta Pontianak, pada 2017 tercatat 463 kasus kecelakaan lalu lintas, dengan total korban meninggal dunia yakni 95 orang, korban luka berat 243 orang dan korban luka ringan 348 orang. Untuk itu penanganan kasus kegawatdaruratan karena kecelakaan baik lalu lintas maupun lingkungan rumah tangga perlu untuk ditingkatkan melalui peningkatan pengetahuan.

Berdasarkan hasil wawancara dengan kader di Puskesmas Perum II Kecamatan Pontianak Barat, didapatkan informasi bahwa kader dan masyarakat di wilayah kerja Puskesmas Perumnas II Kecamatan Pontianak Barat belum pernah mendapatkan pelatihan mengenai BHD dan penanganannya. Selain itu berdasarkan hasil observasi di Puskesmas Perumnas II Kecamatan Pontianak Barat, belum memiliki poster yang menunjukkan apa yang harus dilakukan ketika terjadi kegawatdaruratan. Kader juga menyatakan tidak mengetahui nomor telepon darurat.

Oleh karena itu, mengingat pentingnya pengetahuan dan keterampilan penanganan kegawatdaruratan yang harus dimiliki oleh kader dan masyarakat masih rendah, diperlukan pelatihan penanganan kegawatdaruratan bagi kader dan masyarakat khususnya di wilayah kerja Puskesmas Perumnas II Kecamatan Pontianak Barat.

\section{METODE}

Kegiatan ini dilakukan di wilayah kerja Puskesmas Perumnas II, Kecamatan Pontianak Barat, pada tanggal 9 September 2019. Alasan utama pemilihan lokasi di wilayah kerja Puskesmas Perumnas II ini adalah berdasarkan data dari Dinas Kesehatan Kota Pontianak Tahun 2018, banyaknya kasus kecelakaan yang terjadi di wilayah Kecamatan Pontianak Barat. Selain itu, hasil wawancara dengan kader juga ditemukan bahwa kader belum pernah diberikan pelatihan mengenai keterampilan BHD dan K3 lingkungan rumah tangga. 


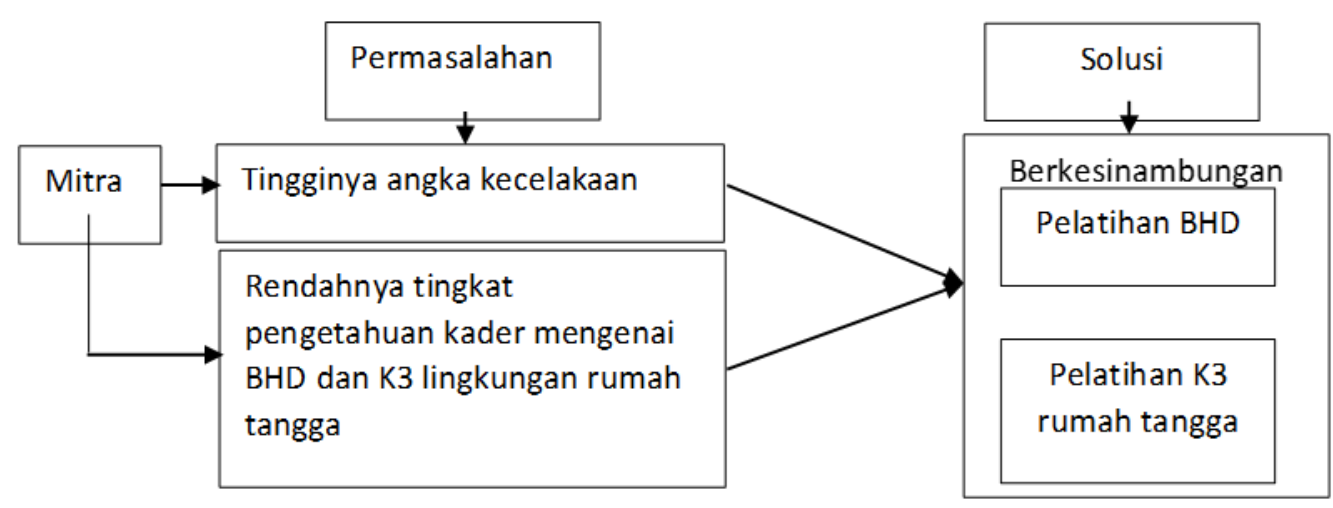

Gambar 1. Alur Kerja kegiatan pengabdian kepada masyarakat.

Adapun dalam kegiatan pengabdian masyarakat ini, sesuai dengan tahapan sebagai berikut :

1) Melakukan kegiatan sosialisasi dengan kepala dan pegawai puskesmas, petugas kesehatan, beserta kader tentang pelatihan penanganan BHD dan $\mathrm{k} 3$ lingkungan rumah tangga.

2) Pengidentifikasian kader kesehatan sebagai calon peserta pelatihan penanganan $\mathrm{BHD}$ dan $\mathrm{K} 3$ lingkungan rumah tangga.

3) Pelatihan penanganan BHD dan K3 lingkungan rumah tangga kepada kader.

4) Evaluasi dan monitoring.

Adapun kontribusi Puskesmas Perumnas II dalam kegiatan pengabdian masyarakat ini sebagai berikut :

1) Mengikuti sosialisasi mengenai Penanganan BHD dan K3 lingkungan rumah tangga.

2) Mengikuti simulasi/demonstrasi penanganan BHD.

3) Mempersiapkan sarana dan prasarana untuk kegiatan sosialisasi dan pelatihan.

4) Melakukan evaluasi dan monitoring.

Indikator keberhasilan pelaksanaan kegiatan ini adalah

1) Indikator input, yaitu : Kader kesehatan bersedia berpartisipasi dalam pelaksanaan kegiatan serta Ketersediaan sarana dan prasarana dalam pelaksanaan kegiatan.

2) Indikator proses, yaitu : Keaktifan bertanya dan berdiskusi saat sosialisasi dan simulasi; Pelaksanaan kegiatan sesuai dengan jadwal.

3) Indikator output, yaitu : Pengetahuan dan sikap kader dan masyarakat tentang penanganan BHD dan K3 lingkungan rumah tangga mengalami peningkatan.

Metode : menguraikan cara yang digunakan untuk menyelesaikan masalah. Contoh metode : a) Pendidikan Masyarakat, misalnya penyuluhan yang bertujuan meningkatkan pemahaman serta kesadaran, b) Difusi Ipteks, misalnya kegiatan yang menghasilkan produk bagi kelompok sasaran, c) Pelatihan, misalnya kegiatan yang disertai dengan demonstrasi atau percontohan untuk menghasilkan keterampilan tertentu, d) Mediasi, misalnya kegiatan yang menunjukkan pelaksana $\mathrm{PkM}$ sebagai mediator dalam menyelesaikan masalah yang ada dalam masyarakat, e) Advokasi, misalnya kegiatan yang berupa pendampingan terhadap kelompok sasaran.

\section{HASIL DAN PEMBAHASAN}

Alat peraga yang digunakan adalah boneka phantom untuk simulasi. Sebelumnya, diberikan materi BHD yang berisi tentang RJP dilaksanakan melalui cara Cardiopulmonary resuscition (CPR) konvensional. dalam melakukan $\mathrm{CPR}$, ada 3 pedoman yang harus kita ingat yaitu A B C :Airway, Breathing, Circulation.

Airway yaitu jalan nafas, setiap korban yang tak sadarkan diri jalan nafasnya akan terganggu sehingga aliran udara ke paru-paru akan terhambat. Tindakan yang harus kita lakukan pada saat itu adalah dengan membuka jalan nafas dengan teknik Head Tilt Chin Lift dan membersihkan benda asing yang menyumbat saluran pernafasan.

Breathing yaitu pernafasan, di sini kita harus memeriksa pernafasan korban dengan cara Look, Listen, dan Feel. Maksudnya adalah look yang artinya melihat adanya pergerakan dada korban, Listen yang artinya mendengarkan suara nafas korban dengan cara mendekatkan telinga kita ke hidung dan mulut, dan feel yang artinya merasakan hembusan udara yang keluar dari sistem pernafasan.

Circulation yaitu pengecekan nadi carotis, menghentikan sumber pendarahan dan kemudian di lakukan kompresi dada sebanyak 30 kali. Kegiatan pengabdian ini dilakukan kepada 33 orang yang merupakan kader di wilayah kerja Puskesmas Perumnas II Kecamatan Pontianak Barat. Adapun karakteristik dari peserta pelatihan ini adalah tertera pada tabel 1. 
Tabel 1. Gambaran Karakteristik Responden (N=33).

\begin{tabular}{|l|l|l|}
\hline Karakteristik & N & \% \\
\hline Usia & & \\
$20-30$ & 5 & 15,15 \\
$31-40$ & 25 & 75,75 \\
$41-50$ & 3 & 9,10 \\
Jenis Kelamin Perempuan & 33 & 100 \\
Pendidikan & & \\
SMP & 7 & 21,21 \\
SMA & 25 & 75,75 \\
S1 & 1 & 3,04 \\
\hline
\end{tabular}

Berdasarkan tabel 1 tersebut mayoritas responden dalam rentang usia 31-40 tahun sejumlah 25 orang $(75,75 \%)$. Sedangkan responden dalam rentang usia 20-30 tahun berjumlah 5 orang $(15,15 \%)$. Responden dalam rentang usia 41-50 tahun berjumlah 3 orang $(9,10 \%)$. Berdasarkan jenis kelamin, seluruh responden adalah kader perempuan (100\%). Sementara itu, berdasarkan tingkat pendidikan sebagian besar responden memiliki jenjang pendidikan tertinggi SMA sejumlah 25 orang $(75,75 \%)$. Responden dengan jenjang pendidikan S1 sejumlah 1 orang $(3,04 \%)$. Responden dengan jenjang pendidikan SMP sejumlah 7 orang $(21,21 \%)$.

Tabel 2. Gambaran tingkat pengetahuan kader terhadap penanganan BHD dan K3.

\begin{tabular}{|l|l|l|}
\hline Variabel & Pre-test & Post-test \\
\hline $\begin{array}{l}\text { Pengetahuan } \\
\text { Baik }\end{array}$ & 10 & 30 \\
Buruk & $(30,30 \%)$ & $(90,90 \%)$ \\
& 23 & 3 \\
& $(69,70 \%)$ & $(9,10 \%)$ \\
\hline
\end{tabular}

Berdasarkan tabel 2 diperoleh bahwa responden dengan pengetahuan baik pada saat dilakukan pre-test hanya berjumlah 10 orang $(30,30 \%)$. Setelah diberikan pelatihan pengetahuan responden dalam kategori baik berjumlah 30 orang $(90,90 \%)$. Hal ini menunjukkan terjadi peningkatan pengetahuan responden setelah dilakukan pelatihan penanganan BHD.
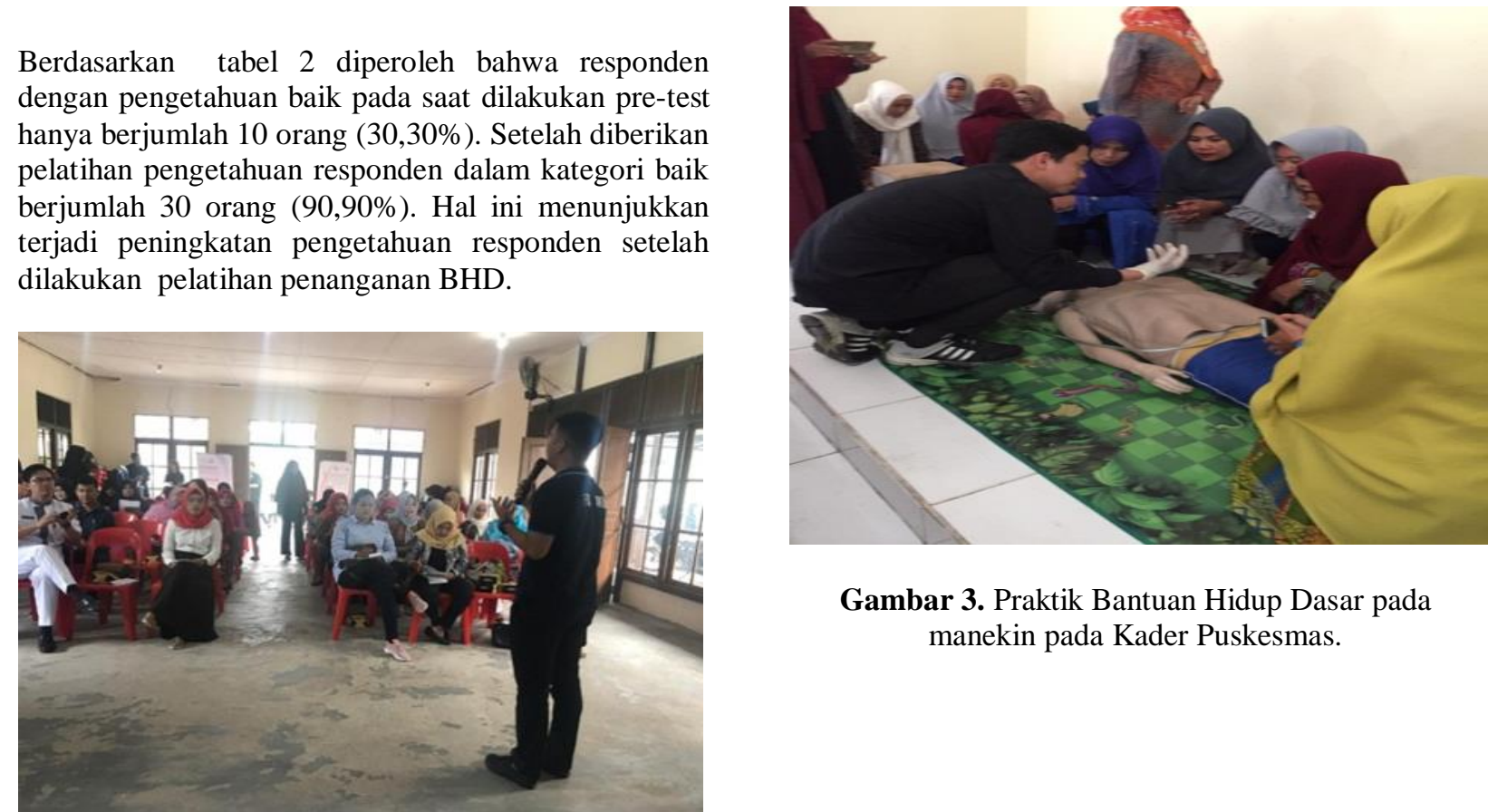

Gambar 3. Praktik Bantuan Hidup Dasar pada manekin pada Kader Puskesmas.

Gambar 2. Penyampaian materi Bantuan Hidup Dasar. 

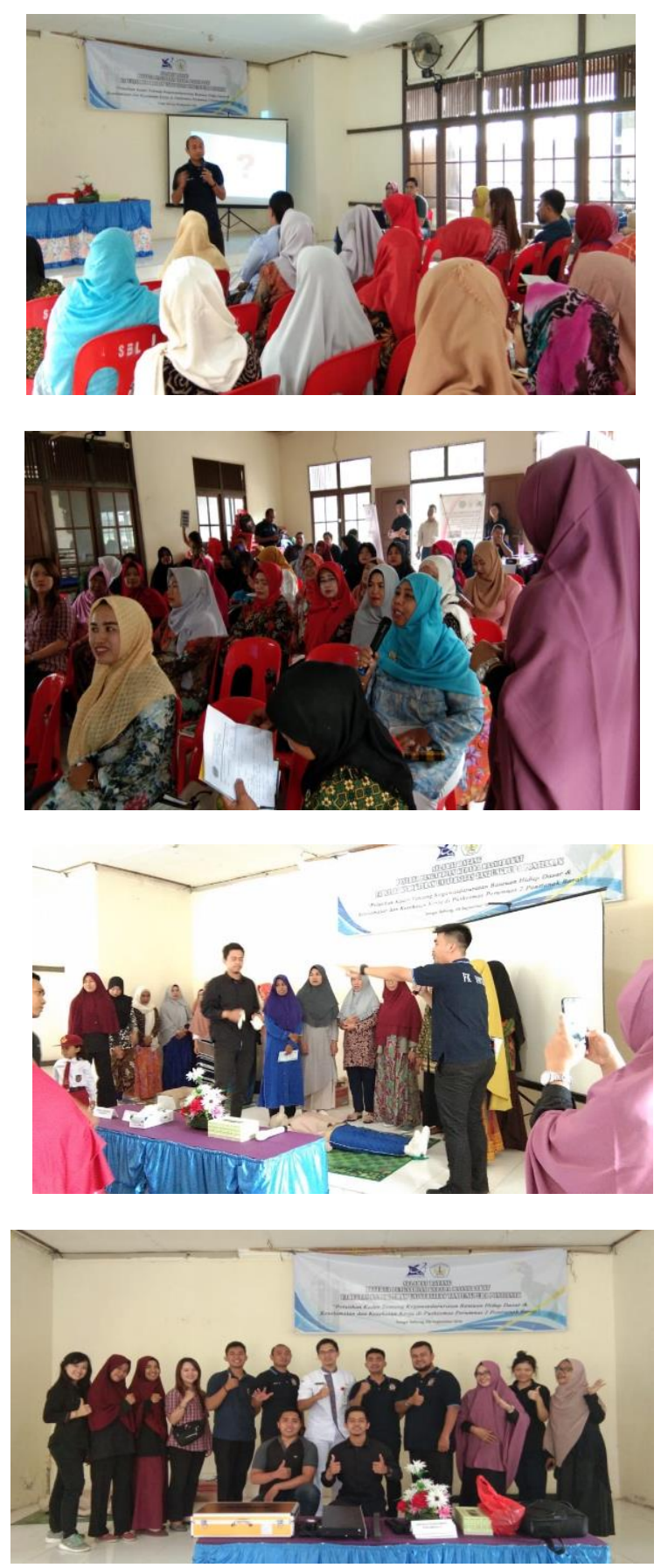

Gambar 4. Narasumber pelatihan bantuan hidup dasar dan kesehatan dan keselamatan kerja.

Berdasarkan hasil pelatihan tersebut dapat dilihat bahwa dengan adanya pelatihan ini dapat menambah pengetahuan kader tentang penanganan BHD dan K3 lingkungan rumah tangga. Pengetahuan merupakan suatu dasar yang harus dimiliki. Dimana salah satu tingkat pengetahuan di dalamnya adalah mengerti dan memahami tentang suatu hal. Dalam hal ini pengetahuan yang didapatkan peserta yaitu mengenai teknik dalam memberikan bantuan hidup dasar khususnya resusitasi jantung paru (RJP).

Tindakan RJP idealnya tidak hanya diketahui oleh petugas kesehatan saja. Akan tetapi, orang awam atau masyarakat pun harus mengetahui bagaimana teknik melakukan RJP. Mengingat bahwa kondisi gawat darurat banyak ditemukan oleh orang awam. Sehingga, penting bagi orang awam atau masyarakat untuk mengetahui dan memahami teknik RJP tersebut. Jika suatu saat mendapati kondisi kegawatdaruratan baik di jalan ataupun dirumah, seperti henti nafas dan henti jantung orang awam tersebut dapat memberikan pertolongan RJP sehingga dapat mengupayakan korban dapat bertahan hidup.

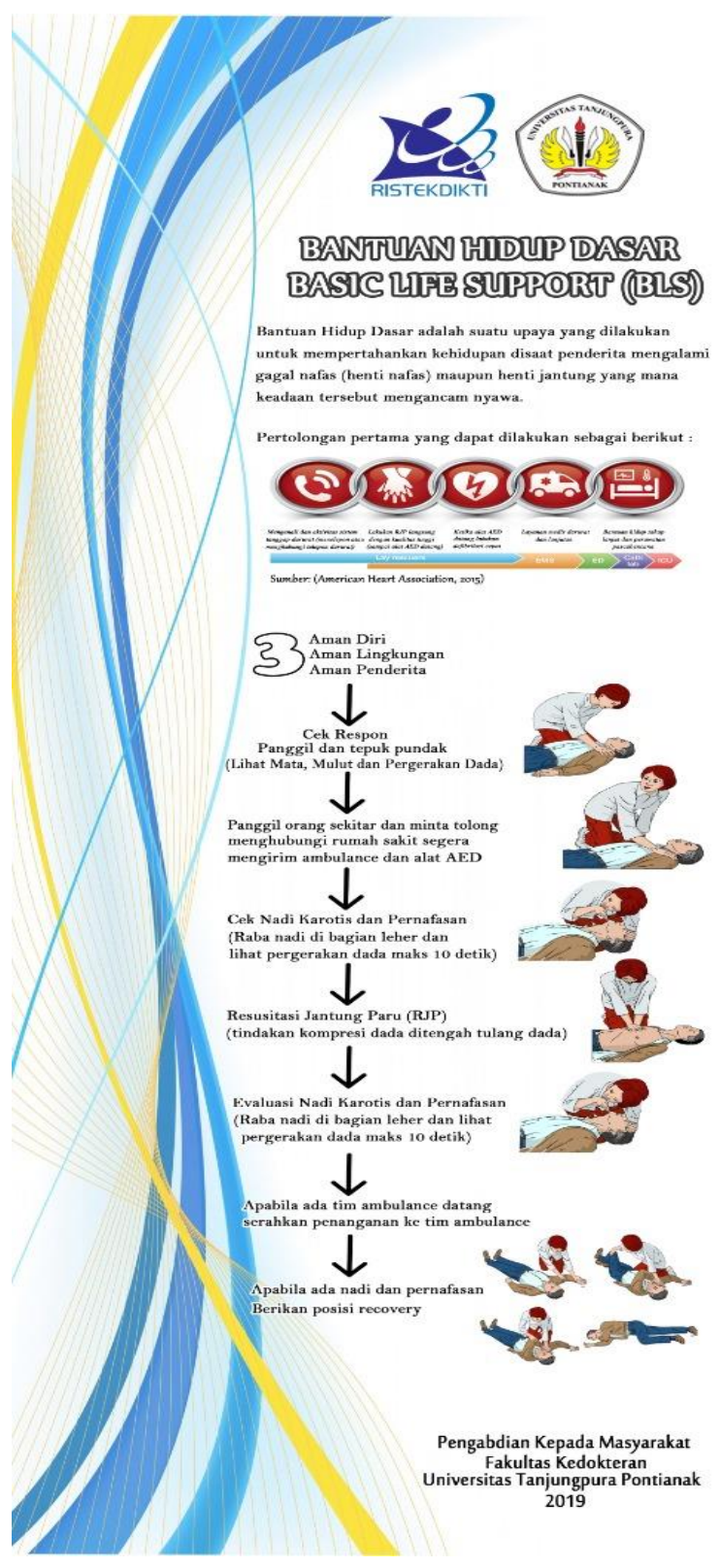




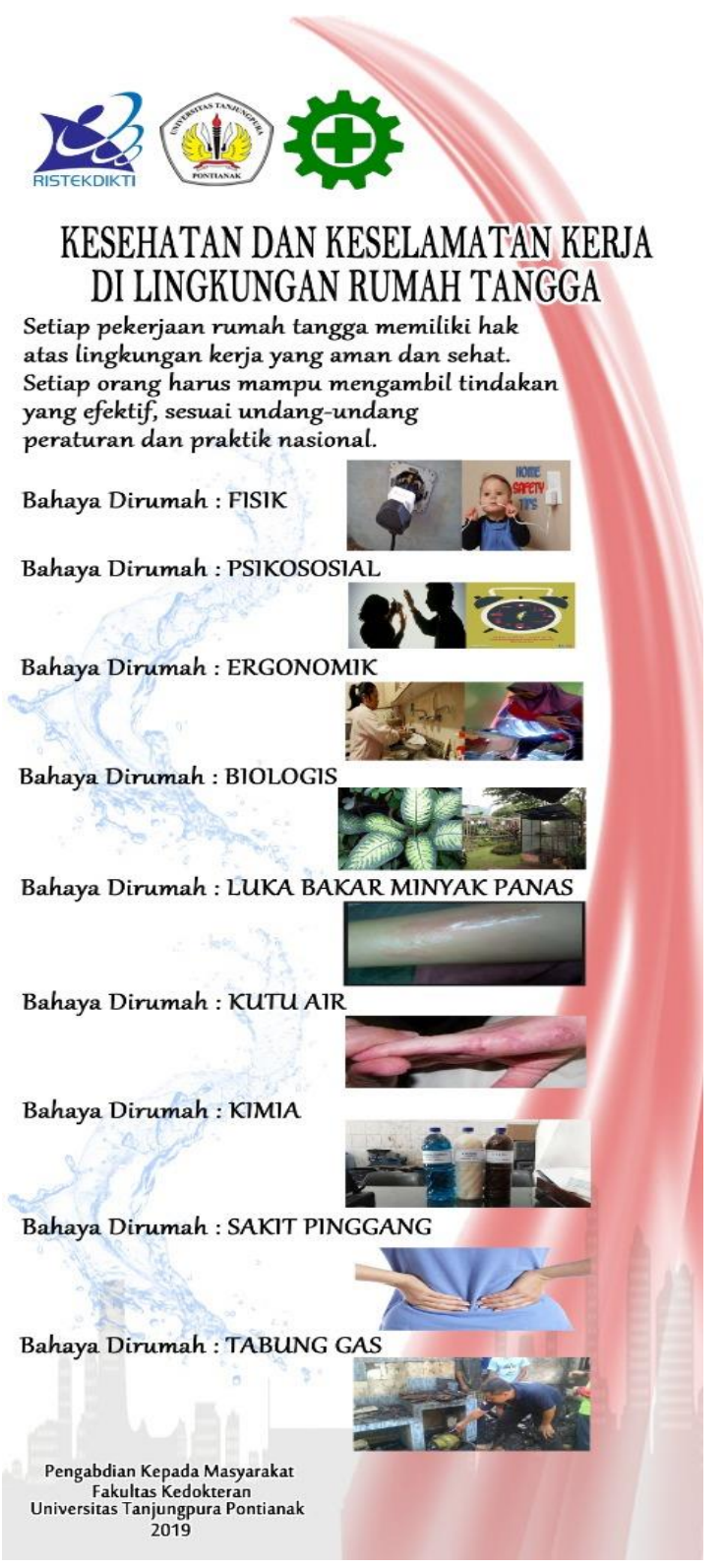

Gambar 5. Alur tatalaksana penanganan BHD dan perhatian pada pada K3.

Adapun kondisi yang perlu dilakukan resusitasi jantung paru yang tertera pada gambar 5 yaitu pada saat ditemukan kondisi henti nafas dan henti jantung dan teknik kompresi. Selain itu, peserta juga diajarkan kapan waktu menghentikan resusitasi jantung paru yaitu dimana telah terdapat tanda-tanda kehidupan seperti teraba nadi dan nafas sudah ada, kondisi penolong yang telah mengalami kelelahan setelah memberikan bantuan secara optimal, petugas medis yang telah datang ke tempat kejadian, serta korban yang tidak berespon setelah diberikan bantuan RJP minimal selama 20 menit dan ditemukan tanda-tanda kematian. Merujuk pada American Red Cross (2015), RJP harus dilakukan secara terus-menerus tanpa berhenti. Namun demikian, RJP dapat dihentikan jika ditemukan tandatanda kehidupan, AED siap untuk digunakan, tim bantuan medis telah tiba, penolong telah merasa kelelahan, dan terdapat situasi yang membahayakan untuk dilakukan RJP.

Dengan adanya pelatihan ini dapat meningkatkan pengetahuan kader mengenai penanganan BHD dan K3 lingkungan rumah tangga. Dari sumber yang lain menjelaskan bahwa ada pengaruh yang signifikan pelatihan teori bantuan hidup dasar terhadap pengetahuan resusitasi jantung paru siswa-siswi SMA Negeri 1 Toili (Lontoh dkk, 2013). Kader termotivasi untuk mengaplikasikan teknik RJP jika suatu hari nanti menemukan korban dengan kondisi henti jantung maupun henti nafas yang membutuhkan tindakan penyelamatan.

\section{SIMPULAN}

Mayoritas responden berusia dalam rentang 31-40 tahun sejumlah 25 orang $(75,55 \%)$, seluruh kader berjenis kelamin perempuan, tingkat pendidikan kader mayoritas adalah SMA $(75,75 \%)$ serta terjadi peningkatan pengetahuan peserta dengan kategori baik sebesar $45 \%$

\section{UCAPAN TERIMAKASIH}

Terima kasih kepada fakultas kedokteran universitas tanjungpura atas pembiayaan yang sudah dikeluarkan dalam bentuk dana dipa fakultas kedokteran universitas Tanjungpura.

\section{DAFTAR PUSTAKA}

American Red Cross. 2015, Basic Life Support for Healthcare Providers Handbook

Aryani, Ratna \& Amelia Arnis, 2016, pelatihan kegawadaruratan untuk kader, Politeknik Kesehatan Kemenkes Jakata 1.

Balitbangkes, 2013, Badan Penelitian dan Pengembangan Kesehatan Kementrian Kesehatan Republik Indonesia.

Fajarwati, D, 2012, Basic Life Support Tim Bantuan Medis FK UII, http://medince.ui.i.ac.id/index.php/berita/BasicLife-Support-Tim Bantuan-Me dis -FKUI.html

Lontoh, Christie dkk, 2013, Pengaruh Pelatihan Teori Bantuan Hidup Dasap Terhadap Pengetahuan Resusitasi Jantung Paru siswa-Siswi SMA Negeri 1 Toili. Ejournal Keperawatan (e-Kp) Volume 1 Nomor (1): 1-5

WHO, 2015, Risk Reduction and Emergency Preparedness, Printed by the WHO Document Production Service, Geneva : Swiitzerland. 